\title{
Investigating of Self-Handcapping Levels of Prospective Teachers According to Sports Activity Variables
}

\author{
Öner Gülbahçe \\ Correspondence: Atatürk University, Kazım Karabekir Faculty of Education, Erzurum, Turkey.
}

Received: January 17, 2019

doi:10.11114/jets.v7i3S.4056
Online Published: February 13, 2019

URL: https://doi.org/10.11114/jets.v7i3S.4056

\begin{abstract}
The research examines self-handicapping levels of prospective teachers according to sports activity variables. The concept of self-handicapping, which is also referred as self-sabotage in the literature, is a mechanism developed by individuals to protect their selves when they cannot achieve a job or when they experience a sense of insufficiency. It is a fact that doing sports has benefits on individuals' mental, physical, emotional, social and psychological health. This research, which presumes the possible relationship between self-handicapping levels of prospect teachers and doing sports, is conducted with relational screening model. The study group consisted of 584 prospective teachers, 359 female and 225 male, studying at Ataturk University Kazim Karabekir Faculty of Education, Erzurum, Turkey, in the academic year of 2018-2019. The data were collected with the "Self-handicapping Scale" and the personal information form prepared by the researcher. The scale was developed by Jones and Rhodewalt (1982) and its Turkish validation and reliability made by Akın (2012). SPSS 21 package program was used to analyze the data. In the analysis of the data, frequency distribution was used to determine the demographic characteristics, the Independent Samples T test was used to examine differentiation status between two independent variables and self-handicapping, and the One Way Anova analysis tests were conducted to examine differentiation status between more than two variables and self-handicapping. All these tests were analyzed in SPSS 21 package program and the significance was evaluated at $\mathrm{p}<0,05$ level.

Findings of the study showed that there was a significant difference between self-handicapping levels of the prospective teachers and gender, family structure, monthly income level, class level and sports activity status. It was concluded that the prospective teachers who were doing sports activities had low self-handicapping levels.

Based on the conclusion that sports activities have a positive effect on self-handicapping levels of prospective teachers, and in order to minimize their self-handicapping levels both in education and social life, the study encourages prospective teachers to engage in different branches of sports according to their interest and talents and offers university administrators to provide sports facilities that the students can use.
\end{abstract}

Keywords: self-handicapping, sports, prospective teachers

\section{Introduction}

People experience so many happy, joyful and beautiful things in their family and work. They can also experience various obstacles and face unhappy, uneasy and troubled events. These inevitable situations help individuals to learn more about the environment they live in and the people around them and to challenge difficulties. However, this process may not always end successfully. Individuals sometimes develop different defense methods towards themselves when they encounter events and situations that they cannot overcome. As a result of these negative events, people have developed defense ways. And one of the defense ways they have developed in order to protect themselves is "self-handicapping."

Edward E. Jones and Steven Berglas were two researchers who used concept of self-handicapping for the first time. According to Jones and Berglas (1978), self-handicapping is individual's attempt for self-justification by considering herself right by finding excuses such as not having necessary capacities to do a task or having doubts about doing a task or not, even though she has necessary skills to do that task or duty. Self-handicapping individuals try to protect themselves by internalizing their success and externalizing their failures. This fact helps individuals to feel better when they are both successful and unsuccessful (Jones and Berglas, 1978; Abacı and Akın, 2011; Üzar-Özçetin \& Hiçdurmaz, 2016). Self-handicapping behavior appears when there are no reasonable and rational explanations of unsuccessful subjects or when there is a fail to make desired events even though the necessary effort has been made to do so (Coşar, 
2012). Self-handicapping behavior which emerges in such cases is actually an obstacle created by individuals on their path to success. It is not individuals' talent or ability to be blamed for the failure of the goal they need to achieve; in contrast, the excuses they created not related to them are the reasons. When individuals become successful despite all of the obstacles, then they can claim the success as a result of their hard work hard. And if they fail, they will be able to relieve themselves by creating reasons of the failure. In this way, they will be able to keep and increase their standing and reputation in society. (Berglas and Jones, 1978; Jones and Berglas, 1978; Leary and Shepperd, 1986; Tice, 2007; Burger, 2006; cited by Üzbe and Bacan, 2013).

When individuals feel they will lose in difficult and challenging social environments they do not want to be seen as incompetent by people around them. When they think that they have not enough skills and when they feel rejection, dislike, failure and fear of making mistakes, they may not work hard but instead they may produce various excuses. This situation, which is an easy lifestyle choice, allows them to relax in the short term, but when it becomes a habit in the long term it may decrease in their self-esteem by deforming the self-perception. Self-handicapping strategies that emerge as a defense mechanism in similar situations help individuals to justify it when they encounter a negative result. All individuals frequently use this defense mechanism in different periods of their lives (Abac1 and Akın, 2011).

Self-handicapping emerges in two ways: behavioral self-handicapping and verbal self-handicapping. Individual can sabotage themselves behaviorally by following ways: they postpone their duties or tasks, show excessive interest in activities that have nothing to do with their real works, overload themselves, put targets difficult to reach, express that they are constantly tired, use alcohol, drugs or pills, cannot realize the opportunities around them, stay in environments that hinder their abilities and postponing. Or they can apply to verbal-handicapping with various excuses by saying that they experience social anxiety, feel negative emotions, experience traumatic events, have health problems and are embarrassed. Behavioral self-handicapping makes individuals to experience more failures than verbal self-handicapping. (Peplau et al, 2010; Abacı and Akın, 2011; cited in: Taş, 2017).

Self-handicapping occurs in certain situations. In particular, the facts that individuals' task has direct connection to their selves and it has important to them or the thought that their performance is monitored by other individuals facilitate emergence of self-handicapping (Eddings, 2003; cited in: Söyleyen, 2018). In this aspect, sports activities can be considered as the environments where people can do behavioral and verbal self-handicapping because of the following reasons; they are considered to be important -both in team sports and individual sports-, sports activities are watched by others, the spirit of winning in sports, necessity to show a good performance. Gözmen-Elmas and Aşç1 (2017) stated that athletes who had low self-esteem and fear of failure in their task have started to reduce their performance by producing negative conditions and disadvantages and exhibited attitudes that would sabotage themselves.

On the other hand, Kuczka and Treasure (2005), who conducted research in the field of sports, stated that individuals' intrinsic motivations for success reduce self-handicapping. In this study, which was conducted with 70 female and 70 male elite university golfers, it was found that the participants who gave less importance to the competitions showed more self-handicapping behaviors during the week before the tournaments than the ones who gave more importance to the competitions. At this point, in case of failure, instead of using active self-handicapping strategy before competitions, it will be more reasonable to create excuses after the competition, which would be less harmful to individuals (Akt. Sarıçalı, 2014). Rhodewalt et al. (1984) also found that the swimmer and the golfers who were doing individual sports and having low self-handicapping tendencies show more efforts in training before the major competitions.

Based on these studies, which have showed that sports activities decrease self-handicapping behaviors of the prospective teachers, in this study it was aimed to determine whether self-handicapping levels differ in terms of sports activities status and then to provide suggestions accordingly.

\section{Method}

\section{Research Model}

This research is a descriptive study of screening model. The model is often used to determine interaction and quantity between two or more variables. Relational screening model, which does not give a real cause-effect relation, allows estimation of the situation in other variable or variables, based on a particular variable (Büyüköztürk, Çakmak, Akgün, Karadeniz and Demirel, 2014).

\section{Participants}

The universe of the study consisted of the prospective teachers studying at Ataturk University Kazim Karabekir Faculty of Education, Erzurum, Turkey, in the academic year of 2018-2019. The sample consisted of 584 prospective teachers, 359 female and 225 male, who was studying at this faculty. The appropriate sample method for the research was selected from the impossible sampling methods. 


\section{Data Collection Tools}

In order to examine the self-handicapping levels of the prospective teachers, one-dimensional Self-Handicapping Scale which was developed by Jones and Rhodewalt (1982), was used. It consists of 25 items. Turkish validity and reliability study of the scale was conducted by Akın (2012). The items of the questionnaire were prepared according to 6-step evaluation ranging from "I don't agree at all" (1) to "I totally agree" (6). The participants can get a minimum of 25 points and a maximum of 150 points. The $3,5,6,10,13,20,22$ and 23 items in the scale are coded in reverse and the total score is calculated from the sum of the scores of all items. The low scores of the scale show that the self-handicapping levels of the participants are low and the high scores show that the self-handicapping levels are high. The Cronbach alpha internal consistency coefficient for this study was found to be, 69 .

In order to determine the demographic characteristics of the participants the personal information form prepared by the researcher, which includes gender, family structure, monthly income, class level, sports activity status was used.

\section{Data Analysis}

In the analysis of the data, frequency distribution was used to determine demographic characteristics, the Independent Samples T test was used to examine differentiation status between two independent variables and self-handicapping, and the One Way Anova analysis tests were conducted to examine differentiation status between more than two variables and self-handicapping. All these tests were analyzed in SPSS 21 package program and the significance was evaluated at $\mathrm{p}<0,05$ level.

\section{Results}

This section presents the demographic characteristics and frequency distributions of sports activity status of the prospective teachers and the results of Independent Samples T test and One Way Anova analysis in order to determine differences between these variables and self-handicapping levels.

Table 1. Demographic Characteristics of the Students

\begin{tabular}{l|l|l|l}
\hline \multirow{2}{*}{ Variable } & $\mathbf{N}$ & $\%$ \\
\hline \multirow{3}{*}{ Gender } & Female & 359 & 61,5 \\
\cline { 2 - 4 } & Male & 225 & 38,5 \\
\cline { 2 - 4 } & Total & 584 & 100,0 \\
\hline \multirow{3}{*}{ Family Structure } & Nuclear Family & 437 & 74,8 \\
\cline { 2 - 4 } & Extended Family & 108 & 18,5 \\
\cline { 2 - 4 } & Separated family & 39 & 6,7 \\
\hline \multirow{3}{*}{ Monthly } & 500 tl and below & 67 & 11,5 \\
\cline { 2 - 4 } & Between 501-1000 tl & 228 & 39,0 \\
\cline { 2 - 4 } & Between 1001-1500 tl & 77 & 13,2 \\
\cline { 2 - 4 } & 1501 tl and above & 212 & 36,3 \\
\hline \multirow{4}{*}{ Class Level } & 1st Class & 174 & 29,8 \\
\cline { 2 - 4 } & 2nd Class & 106 & 18,2 \\
\cline { 2 - 4 } & 3rd Class & 143 & 24,5 \\
\cline { 2 - 4 } & 4th Class & 161 & 27,6 \\
\hline
\end{tabular}

There were in total of 584 prospective teachers, 359 of whom were female and 225 were male. It was observed that the majority of the prospective teachers was in a nuclear family structure and was at 501-1000 TL monthly income level.

Table 2. The Sports Activity Status of the Prospective Teachers

\begin{tabular}{l|l|l|l}
\hline Variable & N & \% \\
\hline \multirow{2}{*}{$\begin{array}{l}\text { Sports Activity } \\
\text { Status }\end{array}$} & Yes & 250 & 42,8 \\
\cline { 2 - 4 } & No & 334 & 57,2 \\
\cline { 2 - 4 } \multirow{3}{*}{$\begin{array}{l}\text { Sports Activity } \\
\text { Type }\end{array}$} & Individual sports & 584 & 1100,0 \\
\cline { 2 - 4 } & Team sports & 122 & 18,8 \\
\cline { 2 - 4 } & Both & 18 & 20,9 \\
\cline { 2 - 4 } & I am not doing sports & 334 & 3,1 \\
\hline \multirow{2}{*}{$\begin{array}{l}\text { Purpose of Doing } \\
\text { Sports }\end{array}$} & Health & 93 & 57,2 \\
\cline { 2 - 4 } & Social activity & 157 & 15,9 \\
\cline { 2 - 4 } & I am not doing sports & 334 & 26,9 \\
\hline
\end{tabular}

The sports activity status of the prospective teachers shows that 250 of them were doing sports activities and 334 of them were not doing sports activities. It was observed that the prospective teachers who were not doing sports activities were higher in proportionate than those who did. It was observed that most of the prospective teachers were doing team sports for purpose of a social activity. 
Table 3. Results of Independent Samples t Test of Gender and the Self-Handicapping Level Scores to Determine If There is Any Significant Difference between them

\begin{tabular}{l|l|l|l|l|l|l|l}
\hline Scale & Gender & $\mathbf{N}$ & $\mathbf{X}$ & $\mathbf{S d}$ & $\mathbf{t}$ & $\mathbf{P}$ & \\
\hline \multirow{2}{*}{$\begin{array}{l}\text { Self-Handicappi } \\
\text { ng Level }\end{array}$} & Female & 359 & 96,30 & 12,13 & \multirow{2}{*}{6,655} & \multirow{2}{*}{$\mathbf{0 0 0}$} & \multirow{1}{*}{$\mathbf{1 > 2}$} \\
\cline { 2 - 5 } & Male & 225 & 89,68 & 10,94 & & & \\
\hline
\end{tabular}

The independent sample t test shows that there is a significant difference between self-handicapping scores of the prospective teachers and gender $(t=6,655 ; p<.05)$. The difference indicates that female prospective teachers had higher self-handicapping levels than the male prospective students.

Table 4. Results of One-Way Variance Analysis (ANOVA) Test of Family Structure and the Self-Handicapping Level Scores to Determine If There is Any Significant Difference between Them

\begin{tabular}{|c|c|c|c|c|c|c|}
\hline Family Structure & $\mathbf{N}$ & $\mathbf{X}$ & Sd & $\mathbf{F}$ & $\mathbf{P}$ & \\
\hline Nuclear Family & 437 & 94,83 & 11,53 & \multirow{4}{*}{8,078} & \multirow{4}{*}{$\begin{array}{l}031 \\
, 004\end{array}$} & \multirow{4}{*}{$\begin{array}{l}1>2 \\
1>3\end{array}$} \\
\hline Extended Family & 108 & 91,42 & 11,98 & & & \\
\hline Separated Family & 39 & 88,15 & 16,16 & & & \\
\hline Total & 584 & 93,75 & 12,11 & & & \\
\hline
\end{tabular}

The one way variance analysis (ANOVA) shows that there is a significant difference between family structures and self-handicapping levels of the prospective teachers $(F=8,078-p<.05)$. According to this result, self-handicapping levels of the prospective teachers within nuclear family structure were higher than the prospective teachers within extended and separated family structures.

Table 5. Results of One-Way Variance Analysis (ANOVA) Test of Monthly Income Level and the Self-Handicapping Level Scores to Determine If There is Any Significant Difference between Them

\begin{tabular}{|c|c|c|c|c|c|c|}
\hline $\begin{array}{l}\text { Monthly } \\
\text { Income }\end{array}$ & $\mathbf{N}$ & $\mathbf{X}$ & Sd & $\mathbf{F}$ & $\mathbf{P}$ & \\
\hline 500 tl and below & 67 & 99,86 & 14,26 & \multirow{5}{*}{9,117} & \multirow{5}{*}{, } & \multirow{5}{*}{$\begin{array}{l}1>2 \\
1>4\end{array}$} \\
\hline Between 501-1000 tl & 228 & 91,58 & 11,50 & & & \\
\hline Between 1001-1500 tl & 77 & 95,59 & 9,76 & & & \\
\hline 1501 tl and above & 212 & 93,49 & 12,12 & & & \\
\hline Total & 584 & 93,75 & 12,11 & & & \\
\hline
\end{tabular}

The one way variance analysis (ANOVA) shows that there is a significant difference between monthly income levels and self-handicapping levels of the prospective teachers $(F=8,078-p<.05)$. According to this result, the self-handicapping levels of the prospective teachers with less than 500 TL monthly income were higher than the prospective teachers with monthly income between 501-1001 TL and with 1501 TL monthly income.

Table 6. Results of One-Way Variance Analysis (ANOVA) Test of Class Level and the Self-Handicapping Level Scores to Determine If There is Any Significant Difference between Them

\begin{tabular}{|c|c|c|c|c|c|c|}
\hline Class Level & $\mathbf{N}$ & $\mathbf{X}$ & Sd & $\mathbf{F}$ & $\mathbf{P}$ & \\
\hline 1st Class & 183 & 94,10 & 10,67 & \multirow{5}{*}{4,232} & \multirow{5}{*}{,006 } & \multirow{5}{*}{$3>2$} \\
\hline 2nd Class & 103 & 90,56 & 12,25 & & & \\
\hline 3rd Class & 143 & 96,04 & 14,30 & & & \\
\hline 4th Class & 155 & 94,41 & 11,17 & & & \\
\hline Total & 584 & 94,04 & 12,15 & & & \\
\hline
\end{tabular}

The one way variance analysis (ANOVA) shows that there is a significant difference between class levels and self-handicapping levels of the prospective teachers $(F=4,232-p<.05)$. According to this result, the self-handicapping levels of the prospective teachers at the 3rd class are higher than the prospective teachers at the 2nd class.

Table 7. Results of Independent Samples t Test of Sports Activity Status and the Self-Handicapping Level Scores to Determine If There is Any Significant Difference between Them

\begin{tabular}{l|ll|l|l|l|l|l|l}
\hline & $\begin{array}{l}\text { Sports } \\
\text { Level }\end{array}$ & Activity & $\mathbf{N}$ & $\mathbf{X}$ & $\mathbf{S d}$ & $\mathbf{t}$ & $\mathbf{P}$ & \\
\hline \multirow{2}{*}{$\begin{array}{l}\text { Self-Handicap } \\
\text { ping Level }\end{array}$} & Yes & & 250 & 88,59 & 11,40 & $-9,570$ & \multirow{2}{*000}{} & $\mathbf{2}>\mathbf{1}$ \\
\cline { 2 - 9 } & No & 334 & 97,61 & 11,17 & & \\
\hline
\end{tabular}

In Table 7, the independent sample $t$ test shows there is a significant difference between self-handicapping scores of the prospective teachers and sports activity status $(t=-9,570 ; p<.05)$. The difference indicates that self-handicapping of the prospective teachers who were not doing sports activity were higher than the prospective teachers who were doing sports. 


\section{Discussion and Suggestions}

It was determined that there is a significant difference between the self-handicapping levels of the prospective teachers and gender, family structure, personal monthly income level, class level and sports activity status.

In the study, it was articulated that the self- handicapping levels of the female prospective teachers were higher than the male prospective teachers. The related literature shows that the self- handicapping level of women is higher than that of men and verbal self- handicapping types is more common among women (Yavuzer, 2015; McCrea et al., 2007; Kolditz and Arkin, 1982; Shepperd and Arkin, 1989). In the study conducted by Kaya et al. on prospective teachers it was found that that self-handicapping levels of female prospective teachers were higher than male prospective teacher (Kaya, et al, 2017). These results support result of our study also. The reason of the result can be due to the fact that women have high ambition and perseverance to finish a task, but when they face difficulties and could not finish the task they do not point themselves as the reason of the failure, and instead they find other reasons and try to find a way to self-handicapping. In other studies, it was determined that men have higher self-handicapping levels than women (Jones and Berglas, 1978; Hirt, Deppe and Gordon 1991; Hirt, McCrea and Kimble, 2000; Kimble and Hirt, 2005; Anli, 2011). In some studies, it was found that self-handicapping behavior does not differ according to gender (Barnes, 2004; Brozowski, 1999; Cowman and Ferrari, 2002; Dorman and Ferguson, 2004; Kinnon and Murray, 2007.Akt: Üzbe, 2013). In Turkey the studies done by Coşar (2012), Üzbe (2013), Yalnız (2014), Çingöz (2015), Civan et al. (2015), Taş (2017), Söyleyen (2018), also state that self-handicapping behavior does not differ according to gender.

The research determined that there is a difference between self-sabotage levels of the prospective teachers according to different family structures. Self-handicapping levels of the prospective teachers in nuclear family structure were higher than the prospective teacher in extended and separated family structures. In the literature, one study was found which examines differentiation between self-handicapping and family structure variable. The study was conducted by Çingöz (2015) on university students found no significant difference between self-handicapping and family structures.

In the research, a significant difference was found between the self-handicapping levels of the prospective teachers who had different monthly personal income. According to this result, the self-handicapping levels of the students with less than 500 TL monthly income were higher than the prospective teachers with monthly income between 501-1000 TL and with monthly income of $1501 \mathrm{TL}$. Low economic level causes the individuals to suffer in different ways. Individuals experiencing these disadvantages can react to other people around them with various verbal or behavioral excuses which will enable themselves to self-handicapping in order to conceal their situation. However, unlike the result of our study, Anl (2011) found no significant difference between self-handicapping level and perceived income level of university students. Similarly, Taş (2017) and Anlı et al. (2015) also found no significant relationship between selfhandicapping level and economic status. Nonetheless, Taylor, Jenkins and Sacker (2011), which is one of the indirect researches on this relationship, also found that high financial wealth is related to high level of psychological health.

It can be stated that there is a significant difference between self- handicapping levels of the prospective teachers and the class levels. According to this result, the prospective teachers in the 3rd class had higher self-handicapping levels than the other classes. There is no meaningful consensus in the literature about the fact that self- handicapping level can create a differentiation on the class level. In some studies (Kimble et al., 1998; Flemming, 2007), self- handicapping was differentiated according to the class level, and as the class level increased, self-handicapping was reduced in individuals. In some studies (Leonardi and Gonida, 2007), it was concluded that there was no significant difference between self- handicapping and class levels (cited in Üzbe, 2013). There are studies also in Turkey that support result of our study (Üzbe, 2013).

In the study, a significant difference was found between the self-handicapping scores of the prospective teachers and the sports activity status. It indicates that the self-handicapping levels of the prospective teachers not doing sports activities were higher than the prospective teachers doing sportive activities. It shows that besides physical, mental, psychological and social benefits, sports decreases self-handicapping tendency as well. Studies made by Rhodewalt et al. (1984), Kuczka and Treasure (2005), Gözmen-Diamond and Cook (2017) found that doing sports as amateur or professional players reduced individuals' self-handicapping behavior tendencies.

In the research it was found that the self-handicapping levels of the prospective teachers who were doing individual sports were higher than the ones doing team sports. This result has parallels with the study conducted by Rhodewalt et al (1984). The researchers conducted a study on self-handicapping on two groups of individual swimmers and golfers, and concluded that the self- handicapping rate of the individual increases in parallel with the increase in the importance of performance for the individual. The athletes with low self-handicapping tendencies showed more effort in training before major competitions and the athletes with high self-handicapping tendency exhibited accusatory attitudes such as physical disability or injury (Cited in Söyleyen, 2018; Üzbe, 2013).

It was concluded that the prospective teachers who were doing sports activities for staying healthy have higher 
self-handicapping levels than the prospective teachers who were doing sports as a social activity. It is possible that the prospective teachers doing sports as a social activity were feeling more comfortable and no pressure so they showed less self-handicapping tendencies compared to the prospective teachers doing sports for staying healthy. Unlike this result of the study Çingöz (2015) did not find a significant difference between individuals' purpose of doing sports and self-handicapping tendencies.

The concept of self-handicapping appears as a defense mechanism which individuals use in different ways throughout their lives, but often do not know what it is. In this respect, it is necessary for prospective teachers, as everyone, to be informed about the concept of self-handicapping. They can be educated through seminars by the experts of the field during undergraduate education. Since doing sports activities can make positive changes on self-handicapping tendency, prospective teachers can be encouraged to engage in individual or team sports up to their interest and talents during their university years. University administrations should provide sports facilities where students can develop physical, emotional, social skills and spend time in a healthy way.

\section{References}

Abacı, R., \& Akın, A. (2011). Self-handicapping: A Result of Human Nature's Limited Nature. Ankara, Pegem Publications

Akın, A. (2012). Self-handicapping scale: Validity and reliability study. Education and Science. 37(164), 176-187.

Akın, A., Abacı, R., \& Akın, Ü. (2011). Self-handicapping: A Conceptual Analysis. International Online Journal of Educational Sciences, 3(3), 1155-1168.

Anl, G. (2011). Investigation of the Relationship between Self-handicapping and Psychological Well-being According to Various Variables. Master's Thesis. Sakarya University Social Sciences Institute: Sakarya.

Anlı, G., Akın, A., Şar, A. H., \& Eker, H. (2015). Investigation of the Relationship between Self-handicapping and Psychological Well-being According to Various Variables. Journal of Electronic Social Sciences. Yaz-2015, 14(54) 160-172. ISSN: 1304-0278

Barnes, B. (2004). Gender differences in use of anxiety as a self -handicapping strategy on effort and performance (Doctoral dissertation). Retrieved from ProOuest Dissertations and Thesis Database. (UMI No: 314081)

Berglas, S., \& Jones, E. E. (1978). Drugchoise as a self handicapping strategy in response to non-contingent success. Journal of Personality and Social Psychology, 95(4), 405-417. https://doi.org/10.1037/0022-3514.36.4.405

Brzozowski, D. M. N. (1999). Self-handicapping: Gender differences, perception of classroom goal structure, and the presence or absence of a learning disability. (Master dissertation). Retrieved from ProOuest Dissertations and Thesis Database. (UMI No: EP11915)

Burger, J. M. (2006). Personality (Trans. İ. D. Erguvan Sarığlu). Istanbul: Kaknus. Original Edition: 2004

Büyüköztürk, Ş., Çakmak, E., Akgün, Ö., Karadeniz, Ş., \& Demirel, F. (2014). Scientific research methods. Ankara: PegemA Publications

Çingöz, B. (2015). Investigation of the Relationship between Self-handicapping Levels of University Students and Sports and Different Variables. Master's Tehesis. Ağrı İbrahim Çeçen University, Social Sciences Institute, Department of Physical Education and Sports.

Civan, S., Şar, A. H., Özçelik, B., \& Işıklar, A. (2015). Investigation of the Relationship between Action and Self-handicapping According to Various Variables. The Journal of Academic Social Science Studies International Journal of Social Science Doinumber: http://dx.doi.org/10.9761/JASSS2986 Number: 39 p. 11-21, Autumn III. https://doi.org/10.9761/JASSS2986

Coşar, S. (2012). Investigation of the Relationship between Burnout Levels and Self-Blocking Levels of Employees. Maltepe University Institute of Social Sciences Department of Psychology. Industrial and Organizational Psychology Graduate Program. İstanbul.

Cowan, S. E., \& Ferrari, J. R. (2002). “Am I for real?" Predicting impostor tendencies from self-handicapping and affective components. Social Behavior and Personality, 30(2), 119-126. https://doi.org/10.2224/sbp.2002.30.2.119

Dorman, J. P., \& Ferguson, J. M. (2004). Associations between students'-perceptions of mathematics classroom environment and self-handicapping in Australian and Canadian high schools. McGill Journal of Education, 39(1), 69-86.

Eddings, S. K. (2003). Gender Differences in Self-Handicapping: The Role of Self Construals. Unpublished doctoral dissertation. University of Utah, ABD. 
Fleming, S. D. (2007). Perception of ability, trait affectivity, and self-handicapping behavior in adolescents (Doctoral dissertation). Retrived from ProOuest Dissertations and Thesis Database. (UMI No: 3244139)

Gözmen-Elmas, A., \& Aşçı, H. (2017). Self-handicapping in Athletes: Self-Esteem, Success Goals and the Role of Fear of Failure. Original Research. Turkish Clinics J Sports Sci., 9(3), 108-117. https://doi.org/10.5336/sportsci.2017-55210

Hirt, E. R., Deppe, R., \& Gordon, L. (1991). Self-reported versus behavioral self handicapping. Journal of Personality and Social Psychology, 61, 981-991. https://doi.org/10.1037/0022-3514.61.6.981

Hirt, E. R., McCrea, S. M., \& Kimble, C. E. (2000). Public Self-Focus and Sex Differences in Behavioral Self-Handicapping: Does Increasing Self-Threat Still Make It "Just A Man's Game? Personality and Social Psychology Bulletin, 26, 1131-1141. https://doi.org/10.1177/01461672002611009

Jones, E. E., \& Berglas, S. (1978). Control of Attributions about the Self through Self-Handicapping Strategies: The Appeal of Alcohol and the Role of Underachievement. Personality and Social Psychology Bulletin, 4, 200-206. https://doi.org/10.1177/014616727800400205

Jones, E. E., \& Rhodewalt. E. (1982). The Self-Handicapping Scale. (Available from the authors at the Department of Psychology, Princeton University. Princeton, NJ 08540.

Kaya, Ç., Şar, A. H., Uğur, E., \& Ercengiz, M. (2017). Self-handicapping and irrational beliefs about approval in a sample of teacher candidates. Kastamonu Education Journal, 25(3), 869.

Kimble, C. E., \& Hirt, E. R. (2005). Self-Focus, Gender and Habitual Self-handicapping: Do They Make A Difference in Behavioral Self-Handicapping? Social Behavior and Personality, 33, 43-56. https://doi.org/10.2224/sbp.2005.33.1.43

Kimble, C. E., Kimble, E. A., \& Croy, N. A. (1998). Development of Self-Handicapping Tedencies. Journal of Social Psychology, 138(4), 524-534. https://doi.org/10.1080/00224549809600406

Kinnon, M. C., \& Murray, C. B. (2007). A profile of college self-handicapper. UCR Undergraduate Research Journal,1, 13-17.

Kolditz, T. A., \& Arkin, R. M. (1982). An Impression Management Interpretation of The Self-Handicapping Strategy. Journal of Personality and Social Psychology, 43(3), 492-502. https://doi.org/10.1037/0022-3514.43.3.492

Kuczka, K. K., \& Treasure, D. C. (2005). Self-handicapping in competitive sport: influence of the motivational climate, self-efficacy, and perceived importance. Psychology of Sport and Exercise, 6(5), 539-550. https://doi.org/10.1016/j.psychsport.2004.03.007

Leary, M. R., \& Shepperd, J. A. (1986). Behavioral self-handicaps versus self- reported handicaps: A conceptual note. Journal of Personality and Social Psychology, 51(6), 1265-1268. https://doi.org/10.1037/0022-3514.51.6.1265

Leondari, A., \& Gonida, E. (2007). Predicting academic self-handicapping in different age groups: The role of personal achievement goals and social goals. British Journal of Educational Psychology, 77, 595-611. https://doi.org/10.1348/000709906X128396

McCrea, S. M., Hirt, E. R., \& Milner, B. J. (2007). She Works Hard for The Money: Valuing Effort Underlies Gender Differences in Behavioral Self Handicapping. Journal of Experimental Social Psychology, 44, 292-311.

Peplau, L., Sears, D., \& Taylor, S. E. (2010). Social psychology (2nd edition). Ankara: Image Bookstore.

Rhodewalt, F., Saltzman, A. T., and Wittmer, J. (1984). Self-Handicapping Among Competitive Athletes: The Role of Practice in Self-Esteem Protection. Basic and Applied Social Psychology, 5(3), 197-209. https://doi.org/10.1207/s15324834basp0503_3

Sarıçalı, M. (2014). An Investigation of Self-Discrimination Perceptions of Pre-service Counselors in Terms of Originality and Supervision. Master's Thesis. Department of Educational Sciences (Guidance and Psychological Counseling). Anadolu University Institute of Educational Sciences.

Shepperd, J. A., \& Arkin, R. M. (1989). Determinants of self-handicapping: Task importance and the effects of pre-existing handicaps on self-generated handicaps. Personalityand Social Psychology Bulletin, 15, 101-112. https://doi.org/10.1177/0146167289151010

Söyleyen, N. H. (2018). The Relationship between Social Concern and Self-handicapping Behavior in University Students. Master's Thesis. Üsküdar University Social Sciences Institute Department of Clinical Psychology. İstanbul.

Taş, R. (2017). Investigation of the Effects of Interpersonal Competence Levels on the Self-handicapping Tendency of 
University Students in their Romantic Relationships. Master's Thesis. Erciyes University Social Sciences Institute Sociology Department Marriage and Family Psychology Program. Kayseri.

Taylor, M., Jenkins, S., \& Sacker, A. (2011). Financial Capability, Income and Psychological Wellbeing, Working Paper, Institute for Social and Economic Research (University of Essex), 2011-18.

Tice, D. M. (2007). Self handicapping. In F. B. Roy, \& D. V. Kathleen (Eds.), Encyclopedia of social psychology (pp. 830-831). California: SAGE. https://doi.org/10.4135/9781412956253.n491

Üzar-Özçetin, Y. S., \& Hiçdurmaz, D. (2016). Self-handicapping and its impact on Mental Health. Current Approaches in Psychiatry, 8(2), 145-154. https://doi.org/10.18863/pgy.13806

Üzbe, N. (2013). The Role of Success Target Orientation, Self-Esteem and Academic Success in Helping Self-Blocking. Master's Thesis. Gazi University Educational Sciences Institute Department of Guidance and Psychological Counseling. Ankara.

Üzbe, N., \& Bacanl1, H. (2015). Success Target Orientation, Self-Esteem and Role of Academic Success in Controlling Self-Blocking. Turkish Journal of Educational Sciences, 13(1), 33-50.

Yalnız, A. (2014). Investigation of the Relationship between Perceived Parents' Attitudes, Self-handicapping and Self-Efficacy. Master's Thesis. Sakarya University, Educational Sciences Institute, Eğitimde Department of Psychological Services.

Yavuzer, Y. (2015). Investigating the relationship between self-handicapping tendencies, self-esteem and cognitive distortions. Educational Sciences: Theory and Practice, 15, 879-890. https://doi.org/10.12738/estp.2015.4.2434

\section{Copyrights}

Copyright for this article is retained by the author(s), with first publication rights granted to the journal.

This is an open-access article distributed under the terms and conditions of the Creative Commons Attribution license which permits unrestricted use, distribution, and reproduction in any medium, provided the original work is properly cited. 